\title{
Nehru - the spirit of Humanism
}

\author{
L.sujatha \\ ${ }^{1}$ (Research scholor,Department of English,AU PG campus,Kakinada Esat Godavari District)
}

\begin{abstract}
:
"Reason in the serve of compassion"-Eysenck

A largely accepted enunciation to describe humanism as the supremacy of the spirit of man and the high ideals of justice and equity imbued with compassion, from all angles and in all walks of life. Today our society and the world have to remind themselves that the spirit of humanism which suffuses and radiates from Nehru's writings and speeches, not only provides the healing touch but also paves the path constructively for peace, harmony and civilizational progress to which humanity aspires. Nehru was not a religious man in the ordinary sense, but was imbued with a profound love for and belief in the people of India, and indeed of the world. What he called secularism was in fact a combination of humanism and pluralism.

"Human values through human self - reliance". Nehru's humanism brings out both these elements quite eloquently - his passionate empathy with the toiling masses of India, his advocacy of peace for the war and violence torn humanity in the world and his clear rejection of reliance on supra-human or supernatural powers or beliefs for pursuing any goals.
\end{abstract}

Keywords: humanism, human values, Nehru, pluralism scientific humanism

\section{Nehru - The Spirit Of Humanism}

Nehru would like to see men and women of India going ahead in India's cause and not caring for pain or suffering. The struggle of India is a part of great human struggle to end the suffering and misery of the world. The magic of his message steals the hearts of millions of Indians and undoubtedly moulded the character of Indira and generations of Indians at large.

Nobel Laureate Rabindranath Tagore says about his book An Autobiography "Through all its details there runs a deep current of humanity which overpasses the tangles of facts and leads us to the person who is greater than his deeds and truer than his surroundings."(An Autobiography, cover page) Referring to Maeterlinck's "Life of the Bee" Nehru explains social organization of the insects, art of cooperation and sacrifice for the common good humanity. Further, he says "If mutual co-operation and sacrifice for the good of society are the tests of civilization, we may say that the White Ant and the Ant are in this respect superior to man." (Glimpses of world history, letter II)

India has known the innocence and insouciance of childhood, the passion and abandon of youth, and the ripe wisdom of maturity that comes from long experience of pain and pleasure; and over and over again she has renewed her childhood and youth and age"(The discovery of India,p.343). He tries to prove that India- an ancient land that has been the base and headquarters of some of the world's greatest traditions of philosophy, science and art, and almost all its major religions. His brilliant intellect, deep humanity and lucid style make The discovery of India essential reading for anyone interested in India, both its past and present.

Jawaharlal Nehru was impressed by socialism; it is an established fact. However, socialism was not only an idea for him, but essentially a matter of practice. Indian philosophical tradition and practice served as the undoubted basis of his socialism. It is well proved from his views expressed from time-to-time and also from the measures taken by him during his long tenure of seventeen years as the Prime Minister of the country. He was also influenced by the Western socialism; he loved Marxism, but his ideas related to mixed economy, democratic socialism and his active participation in the non-alignment movement present a clear picture before us. Besides, Nehru's agreement with Gandhian social and constructive programmes; his stress on bringing about change through non-violence based democratic process; and his efforts towards this end well affirms his commitment for the establishment of a socialist society of Indian tradition.

In principle Nehru was committed to socio-economic equality, the foremost and fundamental feature of socialism. But for this he favoured consent and not a revolution. His dream for the establishment of social democracy was to be realized through equal participation of people in governance. For this, he desired to remove all obstacles of the way to reach the goal.

In this regard his following statement is worth quoting here: 
"I am perfectly prepared to accept political democracy, only in the hope that this will lead to social democracy...Political democracy is only the way to the goal and is not the final objective." The final objective is undoubtedly "social democracy."(Speech at National Congress meeting)

Further, Jawaharlal Nehru was also committed in both principle and practice, to bring about a fundamental change in the system under prevailing situation of the country and on the basis of available resources so that the mass poverty could be eliminated. Everybody could get an opportunity to rise even at an individual level. Works, particularly, related to land-reforms and schemes started in cooperative sector during his term as the Prime Minister of India, may be referred in this regard. These acts were in fact important to bring a good harmony between the fundamentals of the concept of socialism and prevailing circumstances of a country of diversities like India to fulfill the needs towards establishing a socialist society.

In this regard we must notice the provisions, particularly, made in the form of allocation of funds for the co-operative sector and programmes related to the development of agriculture and small scale industries in rural areas in the Five Year Plans. we should also observe Nehru's statement in which he had called upon the masses, especially poor, down-trodden and unprivileged of the country to step forward continuously, to strengthen the cause of socialism in India. He had said, "Leaders and individuals may come and go; they may get tired and slacken off; they may compromise and betray; but the exploited and suffering masses must carry on the struggle, for their drill sergeant is hunger."(Speech at lucknow session 1942 July)

Urging his party men, Nehru had said, "We have to plan at both ends. We have to stop the cumulative forces that make the rich richer and we have to start the cumulative forces which enable the poor to get over the barrier of poverty." (Speech at National Congress meeting)In India approximately forty percent of the total population is still under the poverty line. Participation of the masses in the governing of the system, control over resources and role in policy making is not satisfactory. In certain fields the situation is rather grim. Moreover, suicides of farmers are shameful and a matter of acute concern. This undoubtedly raises a question mark on our economic policies; in such a situation Jawaharlal Nehru's warning refreshes our memory. He had said, "If the social and economic burdens of the masses continue and are actually added to, the fight must not only continue but grow more intense." (Speech in the(parliament )

Jawaharlal Nehru's works has explored how he viewed India. Nehru is widely regarded as the architect of modern India. He set India on the path of democracy and nurtured its institution - Parliament, multi-party system, independent judiciary and free press. He also encouraged Panchayati Raj Institution (PRI).He was a great statesman and it was his foresight that he created institutions like Planning Commission, National Science Laboratories and laid the foundation of a vast public sector for developing infrastructure for industrial growth. Along with public sector, Nehru also wanted to encourage the private sector to establish a social order based on social justice that is why he emphasized on planned development. With Nehru's vision India emerged as a leader nation with the policy of Non alignment and the principle of Panchsheel, the five principles of peaceful coexistence at a time when the rivalries of cold-war were playing with humanity. He was deeply involved in the political opposition and was imprisoned numerous times for civil disobedience. The nationalist movement achieved its goal when India gained its freedom at midnight on August 14, 1947. Upon Britain's withdrawal, Nehru became independent India's first prime minister (1947-1964) and a leader of the Non-aligned Movement during the Cold War.

He had distinct vision that eradication of poverty and better living style is possible with the extensive application of science and technology and industrialization. Education to him was very important for internal freedom and development. He was a passionate advocate of education for India's children and youth, believing it is essential for India's future progress. His government oversaw the establishment of many institutions of higher education, including the All India Institute of Medical Science (AIIMS), the Indian Institute of Technology (IIT), the Indian Institute of Management (IIM) and the National Institute of Technology (NIT). Nehru envisioned the developing of nuclear weapons and established the Atomic Energy Commission of India (AEC) in 1948. He was the survivor of India's great cultural heritage and wanted to combine tradition with modernity.

As the ideologue of the Indian Constitution and the Indian polity, Nehru's contribution cannot be denied. It is his doctrine of secularism and his approach to harmonizing the diversities of India. For Nehru secularism did not mean 'a state where religion as such is discouraged. It meant freedom of religion and conscience, including freedom for those who may have no religion'. For Nehru, the word secular was not opposed to religion. Jawaharlal Nehru played a key role in building modern India. He set up a Planning Commission, encouraged development of science and technology, and launched three successive five-year plans. As a result there was huge growth in agricultural and industrial production. He also had great contribution in developing independent India's foreign policy. He called for liquidation of colonialism in Asia and Africa. $\mathrm{He}$ played constructive, mediatory role in some disputes in international arena such in Korean crisis, Suez Canal conflict and so on. The term socialism gained unprecedented currency in the Nineteenth Century, amidst the escalating industrialization in Europe. It also affected the prevalent European tradition of thinking. However, the 
premise of socialism is not merely the outcome of the European tradition of thinking or a product of the process of European industrialization. Rather, the concept claims an antiquity in Indian social philosophy. Therein it was rooted in ideas like Sabe Bhoomi Gopal Ki [all land belongs to Gopal, i.e., God], Vasudhaiv Kutumbakam [the whole world is but one family] and Sarvodaya [progress of all].

\section{Scientific Humanism: Jawaharlal Nehru}

We attach so much importance to the notion of God that according to many thinkers like Voltaire, even if God did not exist it would be necessary to invent Him. According to them, God is a psychological necessity for "the mind of man has always been trying to fashion some such mental image or conception which grew with the mind's growth".

In addition, it is our natural tendency to depend on someone else - who we consider to be superior to us in all aspects - in knowledge, competence, power and perfection, for instance. God is the paradigm of virtues and ideals cherished, on whom we can rely in times of crisis and whom we can blame for our failures.

Countering the argument of those who upheld the necessity of God or a God-like concept, Nehru argued, "Even if God exists, it may be desirable not to look up to Him or to rely upon Him." He argued, "Too much dependence on supernatural factors may lead, and has often led, to a loss of self-reliance in man." It would, according to him, ultimately result in "blunting of his (man's) capacity and creative ability".

Nehru had a tremendous faith in the human. In order to show the supremacy of man over God he argued, "God we may deny, but what hope is there for us if we deny man and thus reduce everything to futility."

Instead of having faith in God and religion Nehru advocated humanism - which he termed as 'scientific humanism'. It represents 'synthesis between humanism and scientific spirit'. Scientific humanism advocated by Nehru "is practical and pragmatic, ethical and social, altruistic and humanitarian. It is governed by practical idealism for social betterment".

The doctrine of scientific humanism rejects the philosophic, mystic or theoretical approach to humanism in which the quest is primarily for ultimate reality and for individual salvation. For scientific humanism on the contrary, "humanity is its God and social service its religion". It recognizes the fact that "every culture has certain values attached to it, limited and conditioned by that culture". It also recognizes that human nature is such that "every generation and every people suffer from the illusion that their way of looking at things is the only right way or is, at any rate, the nearest approach" to knowing and realizing the truth to which they accord permanent validity.

Scientific humanism wins over this general tendency and upholds a radically opposite view, namely that "the values of our present-day culture may not be permanent and final; nevertheless they have an essential importance for us for they represent the thought and spirit of the age we live in". In view of this Nehru concludes that "we have...to function in line with the highest ideals of the age we live in, though we may add to them or seek to mould them in accordance with our national genius".

Nehru's view is that, man continually accepts the challenges faced by him in achieving the targets and goals chosen by him. "Life," according to him, "is a principle of growth, not of standing still, a continuous becoming, which does not permit static conditions." For man, life is a long adventure and an opportunity to test his will and his worth. He does not rest until goals are reached. From every disappointment and defeat, the spirit of man 'emerges with new strength and wider vision'.

\section{Primary Sources}

[1]. Nehru Jawaharlal. An Autobiography. Volume I, penguin publication, 2004

[2]. Nehru, Jawaharlal, The Discovery of India Volume I, penguin publication, 2004

[3]. Nehru, Jawaharlal, Glimps es of World history, Volume I, penguin publication,

\section{Secondary Sources}

[4]. Other Writings by authors

[5]. Swami Vivekananda. 'India' Volume-I. Advaita publication. 1947

[6]. Tagore Rabindranath. 'The Greater India' Rupa publications.2003

[7]. Tagore Rabindranath. 'Nationalism' Rupa publications.2002

[8]. B. Articles

[9]. A. Eswara Reddy "Nehru's vision", 14 November

[10]. C. Internet Sources

[11]. Ramachandra Guha, 'Nehru and India', Online Edition of India's National Newspaper, November , 2000, The Hindu, http://www.hinduonnet.com/2000/11/14/stories/13140782.htm

[12]. M.chalapathi, 'The first Indian socialist leader -Nehru Jawaharlal Nehru "October 282011 ,

[13]. http://yabaluri.org/TRIVENI/jawaharlalnehrufirstindiansocialistleaderoct89.htm

[14]. Gandhi Speech http://www.indiatogether.org/2004/jun/opi-renehru.htm.1.1

[15]. Nehru speech 'Tryst with Destiny', August 14, $1947 \mathrm{http} . / /$ en.wikipedia.org/wiki/

'Advance Democracy'(on line article) october19, 2011 http://e4e.bravehost.com/qdv 